\title{
Surrogate mother for endangered Cupressus
}

\section{A rare cypress tree increases its chances by using a clever reproductive strategy.}

n n higher plants, the embryo generally derives from the fusion of male and female gametes, although it may sometimes develop from only female cells. Here we show how the diploid pollen of the Mediterranean cypress tree Cupressus dupreziana naturally produces an embryo without fertilization that is nourished in the seed tissues of a surrogate mother, Cupressus sempervirens. This reproductive strategy of paternal apomixis, which to our knowledge has not been seen before in plants, could be an adaptation by this species in response to the threat of extinction.

The life cycle of plants generally alternates between two generations: the diploid sporophyte that produces haploid spores by meiosis, and the haploid gametophyte that produces gametes. Fertilization of a female gamete by a male gamete gives rise to a zygote that produces an embryo, the new sporophyte. However, in apomictic plants the embryo develops from maternal cells without fertilization ${ }^{1}$. Apomixis has been frequently reported in angiosperms but was

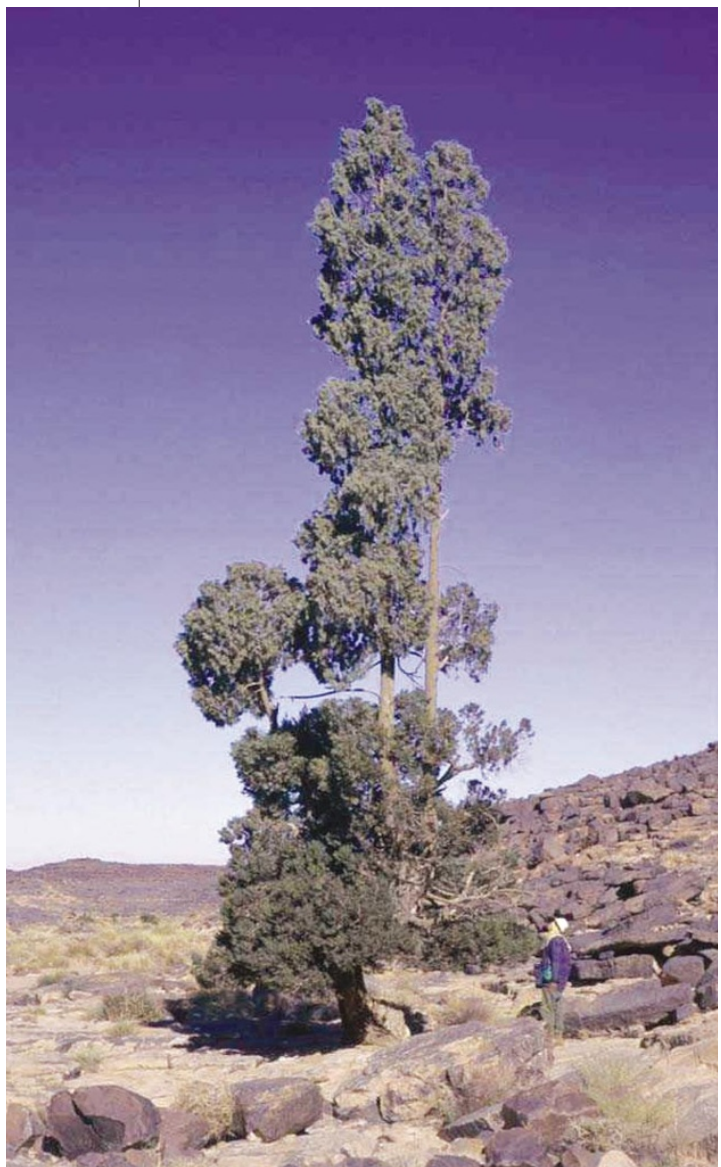

Figure 1 The cypress Cupressus dupreziana is native to the inhospitable Tassili N'Ajjer desert of Algeria and is one of the world's most endangered trees, with only 231 remaining. thought not to occur in gymnosperms ${ }^{2}$.

We have previously discovered significant anomalies in the reproductive structures of a Mediterranean gymnosperm, Cupressus dupreziana A. Camus (Fig. 1). In this variant, viable pollen (male gametophyte) is diploid ${ }^{3}$, embryos do not have the same allozymes as their mothers ${ }^{4}$, and the endosperm (seed nutritive tissue) is not haploid $^{5}$, although in gymnosperms it is derived solely from the female gametophyte ${ }^{6}$. These anomalies suggested that the embryo results from the development of diploid pollen ${ }^{4}$ and led us to examine six 15 -year-old families produced by controlled crosses of Cupressus sempervirens L. (as female) $\times$ C. dupreziana (as male). C. sempervirens is native to the eastern Mediterranean basin and has been widely propagated; C. dupreziana is native to the Tassili N'Ajjer desert of Algeria ${ }^{7}$ and is one of the most threatened trees in the world.

We compared the characteristics of C. sempervirens $\times$ C. dupreziana progeny to those of their parents by using the following morphological and cytological traits to differentiate the two species $^{3,5,8}$ : orientation of terminal twigs (in one plane in C. dupreziana; in all directions in C. sempervirens); female cone size (larger in C. sempervirens); percentage of filled seeds (always low in C. dupreziana); endosperm ploidy levels (only even levels: $2 n, 4 n, 6 n \ldots$ in C. dupreziana); pollen diameter $(38 \mu \mathrm{m}$ in C. dupreziana; $28 \mu \mathrm{m}$ in C. sempervirens); and pollen ploidy level (diploid in C. dupreziana). For all these traits, all progeny were identical to the male tree, C. dupreziana.

We assessed genetic diversity using two types of marker: isozymes (seven polymorphic systems: Fest, Idh, Lap, 6Pgd, Pgi, Pgm and Skdh) in one C. sempervirens $\times$ C. dupreziana family, and random amplification of polymorphic DNA (RAPD; four operon primers: OPA-08, OPA-15, OPA-18 and OPR-07) in four families. A biparental, codominant inheritance was previously reported in $C$. sempervirens for these isozymes ${ }^{9}$, whereas the genetic control of the RAPD markers was unknown. The markers allowed identification of all the parents. Progeny had a single genetic pattern that was strictly identical to that of the father, C. dupreziana (Fig. 2).

Our results confirm at the interspecific level our hypothesis that pollen development in C. dupreziana is apomictic. This leads to the production of embryos that are genetically unrelated to the other seed components (maternal sporophyte and

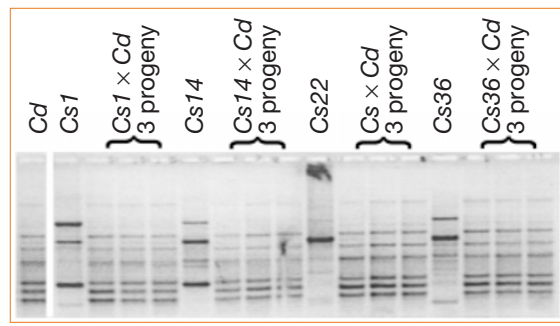

Figure 2 Genetic diversity, as revealed by random amplification of polymorphic DNA markers, among one Cupressus dupreziana tree used as male $(C d)$, four Cupressus sempervirens trees used as females (Cs1, Cs14, Cs22 and Cs36) and 12 progeny produced by the four $C$. sempervirens $\times C$. dupreziana controlled crosses. The operon primer OPA-18 reveals different patterns for the five parents but produces a monomorphic profile for all progeny. This profile is similar to that of the male parent, indicating a strictly paternal origin of DNA.

gametophyte). We have also shown here that another cypress species can be a surrogate mother for this embryogenic pollen. This is, to our knowledge, the first report of paternal apomixis in plants. We suspect that this deviant reproductive pattern evolved in response to the reduction of $C$. dupreziana population size, which is today limited to 231 individuals. Inbreeding in small populations of naturally outbreeding species reduces fitness and increases the risk of extinction $^{10}$. Apomixis, as well as other factors that limit inbreeding, may therefore confer a selective advantage.

Christian Pichot*, Mohamed El Maâtaoui $†$, Sabrina Raddi $\neq$, Paolo Raddi\$

${ }^{*}$ INRA, Unité de Recherches Forestières

Méditerranéennes, Avenue Vivaldi,

84000 Avignon, France

e-mail:pichot@avignon.inra.fr

$\uparrow U M R$ INRA/UAPV Ecologie des Invertébrés,

Département de Biologie, Faculté des Sciences,

33 Rue L. Pasteur, 84000 Avignon, France

\$DISTAF, Florence University,

Via S. Bonaventura 13, 50145 Florence, Italy

\$Institute of Forest Tree Pathology, CNR,

Piazzale Delle Cascine 28, 50144 Florence, Italy

1. den Nijs, A. P. M. \& van Dijk, G. E. in Plant Breeding: Principles and Prospects (eds Hayward, M. D., Bosemark, N. O. \&

Romagosa, I.) 229-245 (Chapman \& Hall, London, 1993).

2. Mogie, M. The Evolution of Asexual Reproduction in Plants (Chapman \& Hall, London, 1992).

3. Pichot, C. \& El Maâtaoui, M. Theor. Appl. Genet. 101, 574-579 (2000).

4. Pichot, C., Fady, B. \& Hochu, I. Ann. For. Sci. 57, 17-22 (2000) 5. Pichot, C., Borrut, A. \& El Maâtaoui, M. Sex. Plant Reprod. 11, 148-152 (1998).

6. Singh, H. Embryology of Gymnosperms (Gebrüder-Borntraeger, Berlin, 1978).

Barry, J. P. et al. Bull. Soc. Hist. Nat. Afr. Nord 61, 95-178 (1970).

8. Gaussen, H. Les Gymnospermes Actuelles et Fossiles (Trav. Lab. Forest., Toulouse, 1968).

9. Papageorgiou, A. C., Bergmann, F., Gillet, E. \& Hattemer, H. H. Silvae Genet. 42, 109-111 (1993).

10. Frankham, R. \& Ralls, C. Nature 21, 441-442 (1998). 